\title{
The Ormulum in the Seventeenth Century: The Manuscript and Its Early Readers
}

\author{
Kees Dekker ${ }^{1}$
}

Published online: 20 December 2017

(C) The Author(s) 2017. This article is an open access publication

\begin{abstract}
The most recent edition of the Ormulum by Robert Holt (The Ormulum, with the notes and glossary of Dr. R. M. White, OUP, Oxford, 1878) pays little or no attention to its seventeenth-century readers and owners: the philologists Jan van Vliet (1622-1666) and Francis Junius (1591-1677). This study aims to fill this lacuna in the reception history of the Ormulum by analysing the study of the Ormulum in the seventeenth and early eighteenth centuries. The results show a vivid and imaginative approach to the Ormulum by its first active student, Jan van Vliet, who discovered its metrical qualities and studied its lexicon. Despite a declining interest in the Ormulum by later scholars, the activities and ideas of its early readers have been a lasting influence on the reception of this unique text.
\end{abstract}

Keywords Ormulum · Reception history · Lexicon · Jan van Vliet · Francis Junius

In 1852, the reverend Robert Meadows White (1798-1865) published the Ormulum in a two-volume edition produced by Oxford University Press. ${ }^{1}$ A fellow of Magdalen College, Oxford, and a former Rawlinson professor of Anglo-Saxon, White had worked from 1832 to 1852 on his Ormulum edition plus glossary, harvesting admiration but also criticism, both at home and abroad (Carlyle 2009). Immediately after its appearance, during Hilary Term of 1853, White's successor John Earle offered lectures on the Ormulum 'as a text-book for the transition period

\footnotetext{
1 The Ormulum is a collection of homiletic material from Oxford, Bodleian Library, Junius 1, written in
} Lincolnshire and dating from c. 1180 (Parkes 1983; Cannon 2007).

Kees Dekker

c.dekker@rug.nl

1 Department of English, University of Groningen, PO Box 716, 9700AS Groningen, The Netherlands 
of the English language'. ${ }^{2}$ In the same year the Leipzig high-school professor C. H. Monicke praised White for 'the exemplary care which has ensured us a correct Text of this poem', but questioned the quality of the glossary: White's etymologies branched out too much into the Germanic languages and were not sufficiently focused on Anglo-Saxon (Monicke 1853: iii-iv; 1854: iii). Later commentators argued that White's transcription was imprecise: in 1877 the Breslau neogrammarian Eugen Kölbing (1877: 1-16) listed some 1100 places in which White had been wrong. Seeking to amend White's misreadings, the reverend Robert Holt published a revised edition in $1878,{ }^{3}$ only to be chastised severely by Kölbing in the next year (1879) for failing to implement the latter's corrections, and criticised more substantially by Sigurd Holm in (1922). Holm's comments were, in turn, criticised by Robert Burchfield (1956: 58), who claimed that Holm's criticism had 'signal weaknesses and inaccuracies' (he had found many more misreadings), and added that editors had, on the whole, been unsuccessful when dealing with the Ormulum. Notwithstanding all discussion-or, perhaps, because of all discussion-White's edition, revised by Holt, is the most recent published one, to date.

White's edition starts with a 100-page Preface, of which the first sixty pages contain a history of Anglo-Saxon scholarship. From the sixteenth-century antiquary John Leland to White's contemporaries, such as John Kemble and Benjamin Thorpe, a long line-up of scholars occupied with Old English are discussed. ${ }^{4}$ Only then does White, rather abruptly, turn to the first seventeenth-century readers of the Ormulum: the Dutch philologists Jan van Vliet (1622-1666) and Francis Junius (1591-1677), who are discussed only with respect to the provenance of the manuscript (White 1852: 1xiii-lxvi). The earliest printed reference to the Ormulum was, according to White, a short sample of text in George Hickes's Thesaurus (1703-1705), while Hickes's co-worker Humfrey Wanley received most credit for his accurate description of the manuscript in his Catalogus historico-criticus of Anglo-Saxon manuscripts (Wanley 1705: 59-63). According to White, neither Hickes nor Wanley had identified 'the metrical qualities' of the Ormulum. Instead, White attributed the identification of the Ormulum as verse to the classicist Thomas Tyrwhitt, who had explained the metre of the Ormulum in his Essay on [Chaucer's] Language and Versification (1775), but who had nevertheless 'failed to comprehend the purport of certain peculiarities in its orthography'. Although White's Preface is detailed and very well documented for its time, it gives an account of the Ormulum's early reception and appraisal that is at best incomplete and obsolete, and sometimes wrong. The 1878 revised edition by Robert Holt did little to change this because it

\footnotetext{
2 As published in The Morning Chronicle (29 January, 1853). http://www.britishnewspaperarchive.co.uk.

3 Robert Holt was vicar of All Saints' Church in Hillesden, Buckinghamshire, from 1860 to 1904, and was the instigator of its renovation; see Bucks Herald (19 June, 1875), 6. http://www. britishnewspaperarchive.co.uk.

${ }^{4}$ White's Preface (1852: iii-lxii) contains an annotated history of the study of Old English both in Britain and on the Continent, which is more internationally orientated than John Petheram's (1840) study.

5 White (1852: 1xvii-1xviii; Tyrwhitt 1775, IV: 64-66 [incl. fn. 52], 76-77 [fn. 58], 98 [fn. 69]). White's mention of Tyrwhitt as the one who first identified the Ormulum as verse goes back to Henry Baber's introduction to his edition of the Wycliffe Bible (Baber 1810: 1xiv).
} 
left the Preface well-nigh untouched. ${ }^{6}$ In this article I reconstruct the earliest studies of the Ormulum and investigate how early readers dealt with the complexities of the Ormulum: the fact that it was Middle English rather than Old English, that it was verse rather than prose, and that its spelling deviated from other 'Old English' texts.

\section{Manuscript}

The study of the Ormulum started in the Low Countries with the work of the lawyer, philologist and polyglot, Jan van Vliet, who bought the Ormulum manuscript in February of 1659 from the heirs of the English royalist refugee, Sir Thomas Aylesbury (1576-1658). ${ }^{7}$ Administrator, mathematician, and ancestor of three future queens, Aylesbury had left England for Antwerp in 1649, and moved to the Dutch town of Breda in 1652 (Alsbury 2004). ${ }^{8}$ Apparently, he had with him some of the 'collection of scarce and valuable books, learned and curious MSS', which he had accumulated and which became dispersed during the Civil War when Aylesbury had no income (Innys et al. 1747: 308-309). ${ }^{9}$ It is not unlikely that financial reasons compelled Aylesbury's heirs to sell the Ormulum to van Vliet, who was willing to pay 18 Florins for it. ${ }^{10}$ Seven years later van Vliet died bankrupt, and, together with some 1200 books from his library, the Ormulum was sold in The Hague in July of 1666 (Dekker 1999: 104-108). Its description in the auction catalogue, 'an old parchment manuscript in Swedish or Gothic about the Gospels', suggest that the auctioneers were clueless about it, as they were about many other books. ${ }^{11}$ The Ormulum manuscript was bought either by or for Francis Junius, who was one of the very few people aware of its contents. ${ }^{12}$ Just before Junius died in 1677, he

\footnotetext{
${ }^{6}$ Holt (1878: 1xvii, 1xxi-lxxiv) inserted footnote 111 and much of footnote 117, a list of publications that had come out after White's edition appeared. For recent usage of the Preface, see, for example, Zonneveld (2000: 38), who reiterates White's assertion that Tyrwhitt first identified the Ormulum as verse, as does Solopova (1996).

7 On van Vliet's life and work as a Germanic philologist, see Dekker (1999).

8 Aylesbury's daughter Frances married Edward Hyde, the first earl of Clarendon, whose daughter Anne married James II and was the mother of Queen Mary II and Queen Anne.

9 Daemen-de Gelder and Vander Motten (2010) discuss the financial problems of Aylesbury's son. Clerke (1885: xx, 277) mentions the dispersal of his library due to his 'time of distress abroad'.

10 In London, Lambeth Palace Library, MS 783, f. 73r, van Vliet wrote 'Ex Rithmis Saxonicis M.S.S.E Bibliothecae P.M. Thomæ Alesburiensis Equitis Compositis'; on the fly-leaf of the manuscript he jotted down the substantial price for which he had bought it: 'Jani Vlitii/Bredae 1659, 6 Febr. const. f. 18'. (Cf. Dekker 1999: 113). Nothing more is known about the transaction. In 1659 Aylesbury's wife was still alive, and there was one surviving daughter, Frances, the wife of Edward Hyde, the first Earl of Clarendon, to whom van Vliet sent a letter on 11 January, 1659 (Oxford, Bodleian Library, MS Clarendon 59, 391), the same month in which he made transcripts from the Ormulum.

11 Oxford, Bodleian Library, Mus. Bibl. III. 4․ 1 (16), p. 11. The books were auctioned by Gerard Ameling in the Ridderzaal, The Hague: 'Een oudt Sweeds of Gottisch in Parquement geschreven Boeck over de Evangelium'.

12 The extent of Junius's personal library is unclear (Bremmer Jr 1998: 213-214, 232-235).
} 
bequeathed his collection of manuscripts (including the Ormulum) and a selection of printed books to the Bodleian Library (Macray 1890: 145-147).

The seventeenth-century provenance of the Ormulum has acquired extra salience because of the incomplete state of the manuscript: not only does it lack a substantial part at the end, but from the surviving quires some 27 leaves are missing which were definitely there when van Vliet was transcribing, as we shall see in the next section of this study. ${ }^{13}$ When and how these folios disappeared remains unclear. The numbering of the columns, presumably inserted by Junius in 1659, suggests that at that time the manuscript was bound or kept in an orderly fashion: there are no slips and no corrections. ${ }^{14}$ If the folios had gone missing between van Vliet's death and the auction of his books, I have little doubt that Junius, who was the next owner, would have noticed it, and made a note of it; however, there is no evidence of him doing so. White's assertion 'that there seems no reason to doubt that the manuscript came into the possession of the University in its present mutilated state' is therefore open to question (Holt 1878: 1xxxi), and invites further reconstruction.

More than a decade passed between Junius's bequest of his manuscripts to the Bodleian Library and the compilation of the earliest printed catalogue of Old English manuscripts by George Hickes, whose description of the Ormulum shows no evidence of detailed study; instead, Hickes only specified the genre and guessed about dialect. ${ }^{15}$ Hickes's description was incorporated in an entry for the 1697 catalogue of the Junius manuscripts drawn up by the antiquary and bishop Thomas Tanner, who mentioned 426 columns (paginas), but did not refer to missing ones, and, for all we know, may not have checked. ${ }^{16}$ The first report of the missing folios occurs in Humfrey Wanley's much more detailed description of the Ormulum in his Catalogus (1705: 59-63), in which Wanley listed them and provided detailed comments on the imperfect and incomplete state of the manuscript. At the end of Wanley's description, the state of the manuscript is once again described in a long citation, of which he gives no source:

Ormini nostri Opus (in Capp. supra CCXL distinctum) ex pluribus constitisse libris inde constat, quia in Indice Textuum Evangelicorum totius operis, ad quinquagesimum, adscripsit non nemo manu veteri, huc usq; I uolumen; in quo tamen, omnia desiderantur à Columna CCCCXXVI. In secundo igitur

\footnotetext{
13 Holt (1878: [lxxxviii]) gives White's table of the missing material.

14 White explains in a note to 1.12719 that a small fragment of a vanished leaf was not included in the numeration (Holt 1878: 397). The column numbers were added during the period of van Vliet's ownership. White observed that they were 'marked by a late hand in Arabic numerals' (Holt 1878: 1xxviii). Denholm-Young (in Madan et al. 1937: 963) stated that 'the numeration of the columns [...] is by Junius', information which he derived presumably from Edmund Craster, Librarian of the Bodleian Library from 1931 to 1945, since Heinrich Christoph Matthes (1933: 2) reported that 'Herr Dr. Craster [...] hält es auf Grund des Schriftcharakters für wahrscheinlich, daß diese Ziffern von Junius' eigener Hand stammen.'.

15 Hickes (1689: 144): 'Liber oblongus Ormulum inscriptus, continens Sermones semi-Saxonice in primum caput Luca. - Locutio hujus libri plane devergit ad Veterem Anglicam, seu potius Scoticam Linguam.' (An oblong book, inscribed Ormulum, containing semi-Saxon sermons on the first chapter of Luke ... the speech variety clearly inclines towards the old English, or rather Scottish, language).

16 In Bernard (1697, I: 249). Tanner observed etymologies of various words at the end-possibly an extra leaf—which are no longer there.
} 
volumine extabat caput LVII; in quo Auctori de Dominica Oratione, Paraphrastico suo more, tractandum erat: cujus jacturam non possum non dolere, quippe quod (si extiterat) haud contemnendum Normanno-Saxonicæ Dialectus mihi exhibuisset specimen; ut qui omnia ejusdem Orationis divinæ exemplaria Anglo-Saxonicè \& Anglicè exarata colligere destinavi, \& in certum etiam Ordinem dirigere. Ex quibus, sic in unum collectis, de linguæ Anglicanæ Origine \& Progressu ab annis circiter septingentis, cuivis doctos fas esset Dissertationem instituere. ${ }^{17}$

Whoever wrote this comment was, like Wanley, aware of the lacunae in the Ormulum, ${ }^{18}$ and, like Wanley, a collector of versions of the Lord's Prayer. It is unlikely, however, that Wanley cited himself; instead, the author of the comment may have been someone involved with the compilation of John Chamberlayne's Oratio dominica (1715): either the compiler himself, ${ }^{19}$ or the Oxford Saxonist Edward Thwaites, who provided Lord's Prayers for Chamberlayne's collection and supplied George Hickes with Ormulum excerpts for the Thesaurus (Bennett 1938: 112, 124; Chamberlayne 1715: ******1v). Whoever the author may have been, the comment shows that by 1703 the missing folios in the Ormulum had already caught the eye of one or more Saxonists, who had apparently searched the manuscript for linguistic particulars.

The occasion of the loss of the folios remains a matter for speculation, but there is no reason for their extraction during van Vliet's ownership or during the time that it was in Junius's library. Instead, the most plausible occasion for the loss of the folios is a rebinding of the manuscript, which must have taken place after 1678 when Junius's manuscipts were transported to the Bodleian Library. Like many other Junius manuscripts, the Ormulum was rebound in 'modern pulp boards' after the collection arrived in the Bodleian Library. ${ }^{20}$ Faulkner's collation diagram of MS Junius 1 shows that from each of the quires one or more bifolia (and one singleton) were removed. ${ }^{21}$ The extraction of these leaves from the quires seems completely

\footnotetext{
${ }^{17}$ Wanley (1705: 63). It is certain that the work of our Ormin (subdivided above into 240 chapters) consisted of more than one book, because in the index of Gospel texts in the entire work, someone wrote in an old hand at entry nr. fifty: 'so far in volume I'. However, in it everything is missing from column 426. Therefore, in the second volume there was chapter 57, in which the author paraphrased the Lord's Prayer in his customary way. I regret its loss, inasmuch as it would have provided me with a very valuable specimen in the Normanno-Saxon dialect, had it still existed. I intend to compare all samples of the same Lord's Prayer written in Anglo-Saxon and English and arrange them in a certain order, and, once collected, it will be possible for any scholar to write a dissertation about the origin and development of the English language over circa seven hundred years.

18 Citations from other authors are rare in Wanley's Catalogus, and only occur in the description of the Bodleian manuscripts (pp. 70, 86).

19 John Chamberlayne was Secretary of the Society for Promoting Christian Knowledge while Wanley was Assistant Secretary, and eventually became his successor (Heyworth: 1989: 148-149).

20 The Bodleian Library Records list no Binder's Book from this particular period. However, Oxford, Bodleian Library, Library Records 700, containing lists of seventeenth-century bequests, contains references to books that were to be bound.

21 Faulkner (2010-2013) states that 'Junius numbered the columns' and adds a collation table showing the lost bifolia and their positions in the quires http://www.le.ac.uk/english/em1060to1220/mss_ diagrams/Ox.Juni.1_di.pdf. For the binding Faulkner remarks: 'Bound in modern pulp boards. The
} 
random, ${ }^{22}$ except if they shared damage that needed to be repaired by a book binder. Examples of similar practices can be found in Humfrey Wanley's diaries, in which he mentions dampness and cockling as problems that were frequently remedied by book binders, whose work was sometimes substandard and could lead to loss of content. $^{23}$ The removal of bifolia from the Ormulum for repair and a subsequent mishap at the binding stage may easily explain the loss of folios between 1678 and the description of the manuscripts by Tanner ${ }^{24}$ and Wanley. ${ }^{25}$

The missing folios were an important reason why some of the transcripts and glossaries made by van Vliet between 1659 and 1666 caught the attention of modern scholarship. In the Times Literary Supplement of November 14, 1936, Neil Ker announced his discovery of 49 leaves of excerpts and glossaries from the Ormulum -all in van Vliet's hand. Ker had found this hidden treasure in London, Lambeth Palace Library, MS 783, ${ }^{26}$ a collection of booklets and singletons that had belonged to Jan van Vliet. ${ }^{27}$ In the following year Ker (1940) published 539 lines from van Vliet's transcripts including fragments from lost columns, from which he was able to reconstruct a homily on Luke II from cols. 13-19. Ker's overview of van Vliet's Ormulum transcripts in Lambeth 783 is, however, very concise and pays very little attention to the individual sections, their apparent chronology and the differences in methodology and treatment of the text. As I have shown elsewhere, the transcripts should be divided into six sections:

(a) ff. $51^{\mathrm{r}}-66^{\mathrm{v}}, \underset{\text { excerpts }}{\text { extitled }}$ 'Excerpta
Evangel $<$ ium $>$ I.' 28

\footnotetext{
Footnote 21 continued

binding probably postdates the significant losses the manuscript suffered after Junius had numbered the columns.'

22 Compare, for example, London, British Library, Add. 32246, which consists of leaves removed from Antwerp, Plantin-Moretus Museum 16.2, in all likelihood because of the Old English glosses on these particular leaves.
}

23 See Wright (1960: 119-120), who states that 'a constant stream of complaints is recorded by Wanley about the delinquencies of binders'. The information derives from Wright and Wright (1966, II: 320, ad 3 November 1724).

24 Macray (1890: 161). In 1692, the Junius manuscripts were 'figured, entered in the Curator's books, and yearly examined', which presumably means that the current numbering dates from 1692 .

25 An example of what could happen to manuscripts suffering from damp can be found in Macray (1890: 138): when in 1673 the collection bequeathed to the Bodleian Library by Lord Fairfax had been exposed to moisture, the antiquarian and biographer Anthony Wood dried them 'by spreading them out in the sun upon the leads of the Schools' quadrangle'.

26 Palmer's online 'Description of Lambeth Palace Library MS 783' supersedes Todd (1812: 191).

27 The papers in what is now Lambeth 783 were probably not bound; instead, it was bought as a bundle of notes by William Griffith, secretary to Henry Coventry at the Breda peace negotiations in May 1667. Griffith's name appears on a clipping from an old folder, now pasted on to the third leaf of the manuscript, which also states that he held an MA from Cambridge. Griffith probably bought the manuscript because of van Vliet's preparatory notes for an edition of Aesop's fables, found at the beginning of the manuscript.

28 Ff. $57^{\mathrm{r}}, 58^{\mathrm{r}}, 59^{\mathrm{r}}(1 / 4), 61^{\mathrm{r}}(3 / 4), 63^{\mathrm{r}}, 64^{\mathrm{v}}, 65^{\mathrm{r}}(1 / 2)$ are not Ormulum excerpts but Latin lecture notes on legal studies. 
(b) ff. $67^{\mathrm{v}}-72^{\mathrm{v}}$, excerpts similar to ff. $51 \mathrm{r}-66 \mathrm{v}$, but written in a slightly browner ink.

(c) ff. $73^{\mathrm{r}}-76^{\mathrm{v}}$, the Dedication to the Ormulum, headed 'EXCERPTA Ex Rithmis Saxonicis MSS. e Bibliothecae P.M. Thomae Alesburiensis Equitis Compositis Ex Evangeliis quorum Praefatio sequitur', and then 'MDCLIX Jan $<$ uario $>$ Bredae.', 'Paraphrasis in Evangelia, aut Ormo Monacho Augustiniano Angl $<0>$ Sax $<$ onico $>$. v. Praef $<$ atio $>$ '. ${ }^{29}$

(d) ff. $77^{\mathrm{r}}-81^{\mathrm{r}}$, the preface to the Ormulum, headed 'Aliud Proemium, post evangeliorum Elenchum. ${ }^{, 30}$

(e) ff. $81^{\mathrm{v}}-86^{\mathrm{r}}$, passages from the Ormulum on the right-hand side of the folio, headed on f. 82r 'S. Luc. I. Fuit in dieb $<$ us $>$ Herodis Regis Judææ Sacerdos $\mathrm{q}<$ ui $>$ dam no $<\mathrm{m}>$ ine Zacharias.' After the Ormulum excerpts had been written van Vliet added in a different ink the corresponding Old High German passages on the facing page, headed 'Idem Francice ex Otfridi Lib. I. Cap. IV.' Above the Ormulum excerpts he added 'Idem Anglo-Saxonice'. 31

(f) ff. $87^{\mathrm{r}}-88^{\mathrm{r}}$, excerpts headed 'Evangelium II. S. Luc. II. Expositio largior. Dixit Zacharias ad Angelum $\mathrm{Un}<\mathrm{de}>\mathrm{h}<\mathrm{oc}>$ scia $<\mathrm{m}>$ ? Ego sum senex. ${ }^{32}$

The order of these sections in Lambeth 783 does not reflect the chronological order in which the excerpts were written; instead, as closer examination has shown, (c), (d), (e) and (f) were written well before (a) and (b). The heading to (c) suggests that this was van Vliet's earliest transcription, dating from January 1659 when the manuscript still belonged to Aylesbury's heirs, while (d), (e), and (f) must have been written in the subsequent months. ${ }^{33}$ All of these earlier transcripts involve continuous sections of text from the beginning of the Ormulum, written in a single column in the middle of the page, with annotations on the left and right, some in the same dark brown pen and some in a lighter ink. All of them refer to the manuscript by Bible references rather than by the column numbers from the manuscript, which suggests that at the time of transcription the columns in the manuscript had not yet been numbered. All of them were written in the same, fairly large hand, which was clearly designed to replicate to some extent the hand in the Ormulum. Conversely, the transcripts in (a) and (b) consist of miscellaneous excerpts from columns 10-48 and 53-101 (Ker 1940: 2); they use column numbers as references to the manuscript, and are written in double columns in a smaller hand. This procedure

\footnotetext{
${ }^{29}$ Holt $\left(1878: \mathrm{B} 1^{\mathrm{r}}-\mathrm{B} 7^{\mathrm{r}}\right)$. Van Vliet's text is only on the recto-sides; on $\mathrm{f} .76^{\mathrm{v}}$ after the Dedication it reads: 'fuit in diebus Herodis th. Cap. I.i.5', followed by chapters from the Bible, listed in the order of their occurrence in the manuscript; this is given up after 'XVII Matth. III.1', after which he writes: 'usq<ue> ad CCXLII in Elencho'.

${ }^{30}$ Holt (1878: $\mathrm{D} 8^{\mathrm{v}}$ ). The text on $77 \mathrm{r}-81 \mathrm{r}$ is written on the rectos only; the versos are empty.

31 Holt (1878: 109-244). There are a few comments in the margins on either side. Van Vliet referred to the excerpts as: Luc. I, 5-9 (ff. $81^{\mathrm{v}}-82^{\mathrm{r}}$ ), Luc. I, 10-14 (ff. 82 $2^{\mathrm{v}}-83^{\mathrm{r}}$ ), Luc. I, 15-17 (ff. $83^{\mathrm{v}}-84^{\mathrm{r}}$ ), Luc. I, $18-21$ (ff. $84^{\mathrm{v}}-85^{\mathrm{r}}$ ), Luc. I, 22-24 (ff. $85^{\mathrm{v}}-86^{\mathrm{r}}$ ).

32 Ker (1940: 4-5).

33 In July 1659 van Vliet wrote to his friend (and Junius's nephew) Isaac Vossius that he had compared the Ormulum with the Old High German Evangelienbuch by Otfrid of Weissenburg, which implies that by then (e) had been written. Jan van Vliet to Isaac Vossius; Amsterdam, University Library, III E 9, 229 (cf. Dekker 1999: 377).
} 
suggests that these transcripts were written later, when van Vliet had started the project of compiling a glossary, for which he did not need transcripts of complete texts but only excerpts of those sections which contained the desired lexemes. Since (a) and (b) were most important as sources for material from missing folios, they are most prominently represented in Ker's edition and comments.

The influence of van Vliet's ownership and study of the Ormulum on modern scholarship is not limited to Ker's discovery and publication of the transcripts. Twenty-two years later, these texts were the topic of Robert Burchfield's contribution to the Festschrift for J. R. R. Tolkien. In the early 1950s Robert Burchfield had started a new edition of the Ormulum in the form of a D.Phil. under the supervision of Tolkien, who had been interested in the Ormulum, but had never got round to working on the manuscript, and had delegated the task to Burchfield. ${ }^{34}$ In the Festschrift article Burchfield compiled a list of all words from van Vliet's studies in Lambeth 783 that were 'new or rare' and had not found their way into the Middle English Dictionary or the Oxford English Dictionary (Burchfield 1961: 94111). The articles by Ker and Burchfield are symptomatic of the confrontation between seventeenth-century readers of the Ormulum and their modern counterparts. According to Ker, van Vliet's excerpts were often random, beginning in the middle of a line, and with words from elsewhere inserted; moreover, van Vliet disregarded the peculiarities of Orm's spelling. In fact, Ker (1940: 2-3) stated somewhat disparagingly that van Vliet's interest was merely lexicographical. Reiterating Ker's conclusions while struggling with van Vliet's lexicographical methodology, Burchfield (1961: 95-97) complained about van Vliet's modernisations, misunderstandings and miscopying, and attributes these problems to 'assembly in a hurried manner before van Vliet had fully mastered the orthography of the original'. Although both Ker's and Burchfield's descriptions and characterisations of van Vliet's work are an important chapter in the history of Ormulum studies after White's and Holt's editions, additions to that history still need to be made concerning the identification of verse in the Ormulum, attitudes to its orthography, and early modern lexicography.

\section{The Ormulum as Verse}

Van Vliet's Ormulum transcripts not only preserved material from columns now lost, but they also inform us about his assessment and appraisal of the text. The first thing that strikes the eye is the identification on $\mathrm{f} .73 \mathrm{r}$ the Ormulum as a verse text: 'EXCERPTA Ex Rithmis Saxonicis M.S.S.... Compositis Ex Evangeliis' (excerpts from a manuscript of Saxon verses composed from the Gospels), to which he added a remark explaining the layout of his transcripts: 'vers $<$ us $>$ in MS. conjunctes legi, non discretes ut hic posui' (I have gathered the verses in the manuscript in long lines, not in separate ones, as I have put them here). Looking at the transcripts, one

\footnotetext{
34 See Oxford, Bodleian Library, MS Eng. c. 7284, f. 1, a biographical note by Elizabeth Burchfield (d.d. 10-12-2004), drawn up with the help of Eric G. Stanley, Burchfield's friend, fellow-student and later Bosworth and Rawlinson Professor of Anglo-Saxon; see also Stanley (2004), Simpson (2008).
} 
cannot fail to notice the striking resemblance in layout of van Vliet's lineation with that of White's and Holt's editions. ${ }^{35}$ As an editor of Latin verse and as an author of verse in Latin and Dutch, van Vliet was sensitive to versification, lineation and punctuation. ${ }^{36}$ In 1659 he was already familiar with the idea of biblical verse in Old English through Francis Junius's 1655 edition of the Caedmon poems (the biblical poems from Oxford, Bodleian Library, Junius 11). ${ }^{37}$ The title of Junius's edition, Caedmonis monachi paraphrasis poetica, may well have inspired van Vliet's heading, 'Paraphrasis in Evangelia', above his Ormulum excerpts in Lambeth 783, 73r. For the lineation of Orm's verse lines, however, Junius's Caedmon edition was not van Vliet's inspiration, for Junius had printed the Old English verse in consecutive long lines, with the half-lines of the alliterative verse separated by metrical points, as he had found it in the manuscript. ${ }^{38}$ While in the Ormulum verse lines are also written consecutively, marked in most cases by a punctus at the end and a punctus elevatus to mark the medial pause (Solopova 1996: 433-434), van Vliet did not follow Junius's example in his transcription, but split the lines into halves. That his inspiration for this practice came from a continental analogue appears from a letter from July 1659 in which van Vliet wrote to Isaac Vossius that he was keen to show Junius his Anglo-Saxon codex containing the Gospels [i.e. the Ormulum] written in a manner similar to the Old High German Gospel Harmony by Otfrid von Weissenburg. ${ }^{39}$ Composed in the ninth century and printed in 1571 by the Protestant reformer Matthias Flacius Illyricus, Otfrid's Evangelienbuch was one of the best known Old Germanic texts on the Continent, and a key witness in the Protestant polemic about the early availability of the Scriptures in the vernacular. In the manuscript, the Evangelienbuch had been laid out in long lines with internal rhyme, the two halves marked by a metrical point-just as Orm had done-but in his edition Flacius had split the long lines into two half-lines printed above each other, separated by a virgule. ${ }^{40}$ Very soon after van Vliet first gained access to Ormulum, he must have noticed the similarities with Otfrid's Evangelienbuch, not just in terms of genre, but also of versification. ${ }^{41}$ It was van Vliet, therefore, who first identified the Ormulum as a verse text, and not Thomas Tyrwhitt as White and others asserted.

\footnotetext{
35 It was observed by Ker (1940: 3, fn. 1), whose reference was picked up by Bennett (1938: 323, fn. 2), who mentions that besides van Vliet 'no one else perceived [the verse in the Ormulum] before Tyrwhitt'.

36 For editions and publications, see Dekker (1999: 67-73).

37 Van Vliet had received a copy from from Junius's nephew Isaac Vossius. The copy was auctioned on 11 April 2006 as lot nr. 2374 in the sale of the library of the Earls of Macclesfield (Quarrie et al. 2006: 97).

38 It is remarkable how much Junius was aware of the verse lines in the Caedmon manuscript-Peter Lucas (in Junius 1655, repr. 2000: xx) has pointed out that Junius attempted to correct and add metrical points-but he stuck to the long-line layout and did not provide an explanation.

39 Jan van Vliet to Isaac Vossius; Amsterdam, University Library, III E 9, 229 (cf. Dekker 1999: 377).

40 Flacius's edition derives ultimately from Munich, Staatsbibliothek, Cgm 14, but the text came to him via a transcript made by Achilles Pirmin Gasser in 1560, now Vienna, Schottenbibliothek, Cod. 733; see Kössinger (2009: 77-78).

41 Comparisons between the verse of the Ormulum and that of Otfrid's Evangelienbuch were made again at the end of the nineteenth century; see Menthel (1885: 71-86). Earlier, in Germany the term 'Otfridische Verse' had come to be used for late Old English and early Middle English verse in general.
} 
Van Vliet's identification of the Ormulum as a verse text casts doubt on the idea that George Hickes and Humfrey Wanley failed to recognise its metrical structure entirely. Inevitably, van Vliet must have opined to Junius that the Ormulum was a verse text, and almost certainly this information was also passed on to Thomas Marshall, Junius's closest collaborator on the publication of the Old English Gospels and early mentor of George Hickes. ${ }^{42}$ On account of his political views Hickes, as a non-juror, was effectively barred from inspecting the manuscript, but, instead, depended on the services of the Oxford antiquary Edward Thwaites to supply him with text fragments for his 1705 Thesaurus (Niles 2015: 149-151; Harris 1992: 36-39). ${ }^{43}$ Thwaites's letters to Hickes refer to the Ormulum mostly in the context of verse, without explicitly classifying it as such: On 30 November 1697 Thwaites concluded a long reply to a query by Hickes about Anglo-Saxon verse by stating: 'I design to consult the ormulum'. On 16 August 1698 Thwaites sent Hickes Ormulum transcripts together with a text of Coedmon's Hymn. ${ }^{44}$ Moreover, Thwaites's rather defective transcript of column 330 of the Ormulum was printed by Hickes in his Thesaurus with emendations, including four metrically relevant points where Thwaites had failed to copy them. ${ }^{45}$ Evidently, Hickes had some idea of the structure of the text.

As assistant librarian in the Bodleian Library, Humfrey Wanley will have made his own transcripts from the Ormulum for his description in the Catalogus, which are very precise and even include symbols for abbreviations. By way of introduction Wanley reproduced from Orm's Dedication to Walter a carefully chosen selection of lines, 11. 1-72, 95-116, 129-136 and 323-342, in order to demonstrate to his readers, straight from the horse's mouth, what the Ormulum was, why it was written and by whom. This selection required careful reading on the part of Wanley who left out those passages that were bibliographically less relevant. No less than five times in Wanley's extracts (11. 44, 59, 64, 67, 101) does Orm refer to his work as consisting of rime and ferrs, indicating unambiguously that he was adhering to a prosodically predetermined pattern of syllables or feet. ${ }^{46}$

\footnotetext{
42 Besides Junius, the English philologist and theologian Thomas Marshall (1622-1681) must have known the Ormulum. Marshall, who was chaplain to the Merchant Adventurers in Dordrecht, collaborated with Junius on the edition of the Gothic and Anglo-Saxon Gospels in Dordrecht between 1663 and 1665. Van Vliet, who wrote a Latin poem for this book, was in close contact with them. Marshall became fellow of Lincoln College, Oxford, in 1668 and rector in 1672. Hickes had become a Fellow of Lincoln College in 1664 (Bennett 1938: 43, 50; Harris 1998: 20).

43 In the Thesaurus Hickes (1703-05: 137-138, 165-166) cited the Ormulum twice as samples of the Normanno-Saxon dialect; in the Institutiones grammaticae (1689: 144), he had still referred to it as SemiSaxon.

44 Harris (1992: 194-195 [Thwaites to Hickes, 30-11-1697], 221-222 [idem 16-08-1698], 223-226 [idem 28-08-1698]). It appears from the latter that Thwaites and Hickes discussed the origin of the name of Orm and that Hickes's text on p. 165 of the Thesaurus is copied from this letter.

45 Cf. Hickes (1703-05: 138), and Oxford, Bodleian Library, MS Eng. Hist. c. 6, f. 111. Hickes inserted metrically fitting points after belamp ([1. 1]), gehaten ([1. 4]), crist ([1.9]), sez3p ([1. 17]), but these are by no means his only emendations. The shared mistakes and omissions, including the omission of puss ([1. 11]) shows that Hickes used Thwaites's transcript only.

46 As Tyrwhitt (1775, IV: 65-66), already observed.
} 
It is inconceivable that Wanley simply missed these clues and believed that the Ormulum was a prose text.

Instead, both Hickes's correspondence with Thwaites, as well as Wanley's reproduction of Orm's Dedication, suggest that the question of whether or not the Ormulum consisted of verse was on the table. The fact that Wanley and Hickes printed Ormulum citations as consecutive text in long lines does not, in itself, prove that they considered it to be prose, as the same form is used for citations from Beowulf by Wanley and Judith by Hickes. ${ }^{47}$ The answer to the question of how they regarded the Ormulum may well depend on their ideas of Old English poetics, and it could well be that, at least for Hickes, the structure of the Ormulum did not meet his expectations of what English verse should be like, in terms of metre, syntax, vocabulary and rhythm. ${ }^{48}$ It was thus left to Thomas Tyrwhitt $(1775$, IV: 66) to claim that Orm's lines were fifteen-syllable lines written 'in imitation of the most common species of the Latin tetrameter, iambic'. ${ }^{49}$

The fact that eighteenth-century scholars avoided alluding to the metrical qualities of the Ormulum betrays an attitude that is perhaps best put into words by the Rawlinson professor of Anglo-Saxon John Josias Conybeare in his 'Introductory Essay on Anglo-Saxon Metre', in which Conybeare complains rather scathingly that the Ormulum is 'interesting, as exhibiting a species of blank verse destitute alike of rime and alliteration' and complains of its 'barbarous and unsightly combinations of double letters', before laying it out as Old English verse, in two half-lines with a caesura in the middle, in order to demonstrate 'the [Anglo-Saxon] language in its most disguised and corrupted form' (Conybeare and Conybeare 1826: 1xvii1xviii). ${ }^{50}$ Conybeare's layout was copied by Edwin Guest who printed the Ormulum in long lines with a caesura in the middle in his History of English Rhythms (1838, II, 207-217). ${ }^{51}$ Eventually, it was Benjamin Thorpe (1834: 171-178) who first

\footnotetext{
${ }^{47}$ However, in these cases the verse was referred to, whereas there is no such indication for the Ormulum; cf. Wanley (1705: 218); Hickes (1703-05: 198); see also the Heliand fragments on pp. 189191.

48 Hickes's ideas are set out in ch. XXIII and XXIV of the Thesaurus (1703-05: 177-235). He distinguishes language, metre, rhythm and peculiar difficulties as the cornerstones of Anglo-Saxon poetics (p. 177). Niles (2015: 155) explains that Hickes thought 'in terms of a basically accentual prosody', 'classifies Old English poetic verses according to the number of syllables', and 'analyses their rhythms in terms of Latin dactyls, spondees, and the like'. McCabe (2011: 190-216) explains Hickes's theory in more detail and provides a translation of relevant parts of the Thesaurus.

49 Solopova (1996: 428-431) reviews modern opinions on the origins of Orm's verse.

50 Hickes (1703-05: 134) had explained Semi-Saxon rather unfavourably as a form of the language half way between wine and vinegar; in other words, neither Anglo-Saxon nor English. Bosworth (1838: xxivxxv) still refers to the Ormulum as Semi-Saxon, but does not cite from it in the Dictionary. On John Josias Conybeare's merits with regard to the analysis of Old English metre, see Niles (2015: 198-204).

51 See also Solopova (1996: 432-433). Although Guest's book is a history of poetics, he defends the Ormulum from accusations by Henry Baber (2010: 1xiv), who had claimed in his introduction to Wycliffe's New Testament that the Ormulum 'only produced feeble and erroneous expositions of the oracles of God' and 'frequently violated scripture facts' (Baber, The New Testament, lxiv; cf. Holt 1878: lviii). Guest (1838, II: 218), however, claimed that 'the doctrines of the Ormulum are singularly free from those fatal errors, which the policy of Rome had, at length, succeeded in forcing upon our Church', and contrasts it with 'sermons of contemporary bishops, in which it is hard to say, whether folly or blasphemy must predominate'. These contrasting arguments illustrate that in the nineteenth century the religious dimensions of texts such as the Ormulum were still playing a role in polemic discourse and were a reason
} 
printed the Ormulum in half lines, similar to those of van Vliet, a custom followed by Thomas Wright (1846: 436-438), and ultimately by White.

\section{Spelling and Emendations}

More enigmatic than the verse of the Ormulum were its peculiarities in orthography and palaeography. Viewing it from an Anglo-Saxon perspective, van Vliet consistently described the Ormulum as his own 'Anglo-Saxon manuscript' and remarked in his defence that 'although it was later than all others, its language was still unmixed with Romance or modern French' ${ }^{52}$ In the small collection of Lord's Prayers which he published in (1664) van Vliet referred on p. 38 to the Ormulum manuscript as 'omtrent 400. jaeren oud zijnde' (being about 400 years old), and was therewith not only the first to refer to the manuscript in print, but also the first to suggest a date, and one that is remarkably close to the modern dating. It appears that for van Vliet's classification of the Ormulum as Old English the absence of French vocabulary was deemed more important than its idiosyncratic spelling or its late date.

The first transcripts that van Vliet made, on ff. 73-81r, (c) and (d), of Lambeth 783, reflect Orm's spelling in most cases, including the superscript $r$, the $-e r$ abbreviations and the $b$ with cross bar for $p c e t$, disproving thereby Ker's rather general conclusion (1940: 2-3) that the transcripts are rarely faithful. ${ }^{53}$ In (c) $r$ is insular; double $\mathrm{p}$ resembles $\beta$; the letter wynn is not changed into $w$; capital 3 is insular; and Orm's double graphs are copied verbatim, with both the ordinary double consonants and the superscript ones clearly in place. Not all abbreviations are expanded (e.g. Afft' on 73r, 1. 15), but Orm's pilcrow is duly copied. However, as he copied (e) his faithfulness began to diminish, especially in the case of double consonants. By the time he was transcribing (f) he had given up on wynn, writing $w$ throughout, while the double consonants had become rare in the transcript. These transcripts show that van Vliet's earliest attempts were much more text-oriented and less lexicographically focused. It may well have been van Vliet's visit to Francis Junius in the Summer of 1659 which made him rethink his plans and revise his methodology. Although he continued to transcribe entire verses-almost all lines scan-it seems that he tried to emend consistently, rendering what presumably must have seemed to him better 'Old English'. 54

\footnotetext{
Footnote 51 continued

for scholars to study them. Sharon Turner's The History of England in the Middle Ages (1830, V: 435436) prints consecutive text without any mention of verse.

52 Leiden, Universiteitsbibliotheek, III E 9, 229: 'Est autem recentior omnibus quae extant; nihil tamen Romanici sive hodierni Gallici sermonis admixtum habens'. Although 'unmixed' is wrong, the number of French words is minimal; see Durkin (2014: 266-267).

53 The reason for Ker's generalisation may well be that these transcripts were made from still extant parts of the beginning of the Ormulum from which Ker and Burchfield do not cite.

54 Ker (1940: 4/11-5/60). Nonetheless, we can see van Vliet struggling with the spelling: there are still thirteen instances of the double consonant left.
} 
Van Vliet's desire to regard the Ormulum as Old English resulted in further attempts to emend in such a way that its language did indeed resemble Old English. This appears most strikingly from the manuscript itself, in which van Vliet made alterations and additions. In 1956 Robert Burchfield, who was in the process of preparing his new edition, lifted a corner of the veil. In the first 13,000 lines of the manuscript, Orm had used <eo $>$ spellings for the Old English diphthong /ĕo/eo/ already (partly) smoothed to /ě/or/ē/, in words such as beon, heoffne and leorninng. Later in the manuscript he used the spelling $<\mathrm{e}>$ for the same words. Subsequently, Orm or a scribe tried to change these $<\mathrm{eo}>$ spellings to $<\mathrm{e}>$ by erasing the $<\mathrm{o}>$ of the digraph, to achieve uniformity of spelling in the manuscript (Turville-Petre 1974: 1-27). ${ }^{55}$ Burchfield (1956: 83) signalled that 'in a large percentage van Vliet [...] has superimposed an $o$ in his characteristic pale green ink on the cancelled $o$, thereby eliminating what he must have considered to be scribal corruption of good Old English. ${ }^{56}$ Moreover, in his attempt to re-ink faded hyphens, van Vliet added hyphens in places where Orm did not put them, and in parts of the manuscript inserted little vertical lines to separate words. ${ }^{57}$ The availability of Burchfield's annotated transcripts of the Ormulum gives a much more complete idea of van Vliet's invasive actions in the manuscript, which will shock any modern reader. ${ }^{58}$ In his notes on the text Burchfield writes that 'alterations to the punctuation by van Vliet have been ignored', while he inserts a special category in his apparatus criticus to comment on van Vliet's alterations and additions. Apart from the alterations already mentioned, van Vliet's hand changed words and sometimes phrases, underlined words (presumably because he intended to include them in a glossary), ${ }^{59}$ inserted identification marks as cross-references to Lambeth $783,{ }^{60}$ and inserted miniature capitals and references to the Gospels. ${ }^{61}$ On a number of occasions his emendations found their way into White's (and Holt's) edition: e.g. in line 15 of the Dedication Affterr patt little witt tatt me, he changed the initial $t$ of tatt

\footnotetext{
55 The variation in the Ormulum between $<\mathrm{e}\rangle$ and $<\mathrm{eo}>$ spellings has occasioned numerous publications, beginning with Bülbring (1905: 51-82).

56 That van Vliets 'editorial' activities did not stop at this becomes clear from another note by Burchfield (1956: 66) stating that 'Van Vliet made other important alterations and additions to the manuscript, and these will be dealt with in a paper in due course'.

57 Burchfield (1994: 182-187), mentions all swa, inn till, mann kinn, and on hoen as words hyphened in many cases by van Vliet. However, he also inked over faded hyphens, corrected omissions and in some cases changed hyphens from single to double ones. On the vertical lines separating words, see Burchfield (1956: 66).

58 I am very grateful to Oxford University Press for allowing me to consult Burchfield's annotated transcripts, and to Dr Inge Millful, in particular, for facilitating this. These transcripts are in four folders of unnumbered typed pages, and references to it are by line number of the Ormulum. The transcripts begin with a single leaf of 'notes on the text'. Of the subsequent folia only the recto sides have been used for the Ormulum text; the facing verso sides were used for additional notes to the apparatus criticus. It would seem that Burchfield began by writing out his transcripts by hand and then typed them out. The additions to the apparatus criticus in various types of ballpoint as well as pencil indicate that he revisited the text over a long time, and quite often van Vliet's alterations to the manuscript occasioned these revisions. All of my examples of van Vliet's alterations were derived from Burchfield's editorial work.

59 E.g. cerist (15050), be33en(n) (15091), lott (15186), witegunnge (15188), prowinnge (15205), etc.

${ }^{60}$ E.g. at the bottom of f. $58 \mathrm{r}$ and on f. 59r where the symbol refers to Lambeth 783 , f. $43 \mathrm{v}$.

61 E.g. ff. $68 \mathrm{r}, 78 \mathrm{v}, 101 \mathrm{r}$.
} 
into a $p$, so as to make it patt; in line 8473 galileo was changed into galilew by van Vliet, presumably on the analogy with other $\mathrm{w}$-forms in the text; accents in time (12745) and Cefás (12702) are in van Vliets's hand. Occasionally, he corrected errors in the manuscript: shaffde to shaffte (13980) and pitt to patt (15797). Van Vliet's most frequent emendation, however, concerned MS <e.o. $>$ altered to $<$ eo $>$ as in e.g. preost $(109,293)$, eorp (288), peode (110), streonen (855), to give only a few examples. Many other examples provide evidence of his not always successful engagement with the text, which he attempted to clarify and improve. Although many of these alterations are unfounded and constitute a deterioration of text and manuscript to modern eyes, the idea of recreating a more perfect form of Old English by emendation was not uncommon in the seventeenth century, when scholars such as van Vliet still believed in a linguistic saeculum aureum of the Germanic languages, analogous to similar opinions about Latin and Greek. It appears strongly in Francis Junius's Old English transcripts and editions, and it is not unlikely that behind van Vliet's emendations in the Ormulum there was Junius's influence (cf. Dekker 2000b). Inadvertently, van Vliet's appraisal of the Ormulum in the light of the Old English tradition set a trend which extended perhaps even up to White's preface with its firm emphasis on the history of Old English studies and minimal comparison with contemporaneous Middle English texts or later material. ${ }^{62}$

\section{Lexicography}

In line with Junius's philological paradigm, van Vliet's Ormulum studies consisted mainly of transcribing, excerpting and making glossaries. This lexicographical purpose emerges very clearly from his later transcripts in Lambeth 783, (a) and (b), which were published by Ker (1940) and mined for unrecorded vocabulary by Burchfield (1961). Written on pages folded into two columns, the excerpts, with relevant words underlined, cover the inside columns, while the outside columns contain a scattering of Dutch, English and German cognates and translations as well as cross-references to other Ormulum passages (cf. Dekker 1999: 136-137). Most of the time he underlined single words, but occasionally two consecutive words or an entire phrase were underlined. The choice of lines is not always random; instead, the occurrence of similar words in close proximity, sometimes linked by a dotted line, betrays a purpose: thus, on f. 57r, an eight-line block contains spell and spellen as two forms of one lemma; in the next citations pwerrt ut and pwertut also show a clear aim on his part to investigate a word. The formulaic patterning in Orm's verse receives attention, e.g. 'His wiken was to pewten God'- 'His wiken was to gangen in' (f. 54v), as well as his use of alliteration, 'to wrezen 7 to wrabben' (f. 56r), 'to lesten 7 to luten hem' (f. 55r), and figura etymologica, e.g. in 'peg alle mugen gastlig stren 7 gode dedes strenen' (f. 53r), and 'to lernen haliz lare' (f. 54r), with the relevant words underlined. ${ }^{63}$ Although the ultimate aim of his work can be said

\footnotetext{
${ }^{62}$ Matthews (2000) shows that by the time of White's edition there was a tradition of 'Middle English'.

63 Lehnert (1953: 179-190) lists stylistic figures in the Ormulum. In his use of figura etymologica Orm combined a verb with a cognate object, e.g. '3e shulenn dezenn ifell dæp' (15436).
} 
to be lexicographical, these examples testify to his wider interest in the lexical aspects of the Ormulum. One should bear in mind that in the seventeenth century the concept of lexicography covered a wider berth than today and included what is nowadays regarded as word studies, etymology and even antiquarian studies. The synthesis of this work was a Glossarium Saxonicum, 17 quarto pages, which contain some 1700 entries. The original alphabetical sections of the glossary were complete a long time before van Vliet had finished reading, and in his enthusiasm he subsequently filled most of the pages from top to bottom. Latin and Dutch translations alternate with cognates from Old English, Modern English, Swedish, German, Danish, and even Hebrew. Burchfield claimed that 'when the words are rearranged into strict alphabetical sequence it becomes apparent that the list falls little short of a complete record of the words (though not of the forms and occurrences) in the surviving parts of the Ormulum' (Burchfield 1961: 95). Yet the Glossarium Saxonicum was a working glossary meant as a stepping stone for further exploration.

Evidence of van Vliet's continued glossing exists in the form of a hitherto unnoticed Ormulum glossary contained in his copy of William Somner's Dictionarium Saxonico-Latino-Anglicum, published in Oxford in $1659 .{ }^{64}$ Now in the University Library of Leiden, the dictionary contains van Vliet's marginal annotations including 103 references to the Ormulum. ${ }^{65}$ At the back of the book there is a loose sheet of paper stuck to the board with a pin. ${ }^{66}$ Divided into alphabetically ordered sections (A-R), it contains 206 entries of words or phrases taken mainly from column 203 and after, accompanied by column references and occasional translations. Like the transcripts and glossaries in Lambeth 783, this glossary was compiled when the lost bifolia were still in situ and therefore provides further insight into those parts of the Ormulum now missing. ${ }^{67}$ Although glossaries

\footnotetext{
${ }^{64}$ In addition, there are scattered citations from the Ormulum in his copy of F. Junius, Observationes in Willerami abbatis Francicam paraphrasin Canticum Canticorum (Amsterdam 1655), bound together with Paullus Merula, Willerami abbatis in Canticum Canticorum (Leiden 1598), now Leeuwarden, Tresoar, $1601 \mathrm{Th}$, and in his copy of the incunable edition of the Old Frisian laws, now Oxford, Bodleian Library, MS Marshall 60.
}

65 Most of these marginal annotations from the Ormulum concern variants or additions to Somner's lemmata that he indicated by 'MS. AS. meus', 'MS. AS.', or 'MS', often followed by the column number, e.g., between Somner's Adastrigan and Adeadan, van Vliet added 'Addlen MS. mereri. p. 40.6.137.153.154 $\mathrm{p}<\mathrm{ass}>\mathrm{i}<\mathrm{m}>$ ', which shows that the now lost column 137 contained the form addlenn. Similarly, the annotations show for the columns now lost the occurrence of ald (190), allderrmann (101), apperrmod (116), arrf (39), arrfname (138), sunnebam (21), bididdrenn (203), birrp (27), to bonen god wip benes (21), duhhtig wif (23), cem (101), ummbe (23), immess (184), molenn (72, 77), Hiss clap wass off ollfenntess har (238), shrifenn (101), waccnenn (241), wa me (196), warr (258), wikenn $(24,25)$. I have rendered the words in Orm's spelling.

66 The paper is a blank letter addressed to Abbey of Thorn, a town in the Dutch province of Limburg. Apart from the glossary, there are some scribbles including three word pairs showing that Old English $<$ eo $>$ corresponded to Dutch $<\mathrm{ie}>$, e.g. streona/strienen.

67 The entries from lost columns are: all hemm ane (225), annde (278), ban (278), bigatt [V. bigcete] (243, 244), blunnenn (260), blinnen (203), bitell (238), blasst (278), bresstenn (298), brisstell 7 bitell haz3re (238), domess of wisemenn (222), dregenn (243, 244), drope, waterrdrope (221), eddre (278), effninng 7 efennwage (241), fe (301), fezedd (278), forrganngell 7 bidell (238), forrme lattre (237), ganngenn purrh (222, 224), genge (224), giferrnesse (243), ha33re 7 hoer (238), lacchenn (302), lorenn (222), leornenn (222), lez3kess 7 skemmtinn33 (239), lic (278), malenn (222), naffle (239), rimenn 7 reccnenn (277), rohhte (221). I have rendered the words in Orm's spelling. 
like this should be treated with extreme caution, for it was not at all beyond the compilers, for example, to reconstruct infinitives from declined verb forms or split compound nouns into two, it seems that eleven of the forms listed by van Vliet are unattested and should therefore be added to the Ormulum lexicon:

ban (278) 'bone'. V: 'Ban, been 278. f.' ${ }^{68}$

blasst (278) 'breath'. V: 'Blast, asem, 278. f.'

Van Vliet translated blasst as Dutch asem 'breath. OED, s.v. blast, n.1, cites 'c. 1250 ' as the earliest attestation of this meaning.

blunnenn $(203,260)$ Past plural or past participle of blinnen 'to cease, to leave off'. V: 'Blinnen of, f. na laten 251. f. 1. 9. imp<er> . blunnen. 260. p. 203. blinnen, standen still 7 stinten 310 f.'

$\mathrm{W} / \mathrm{H}$ list blinnepp, blinnen, blan. OED, s.v. blin|blinn, v., states that blunnen is rare and gives no attestations.

brisstell (238) 'bristle and sharp hair shirt'. V: 'Bristell \& bitel hagre 238 f. 1.4.'

The form hazzre was listed by Burchfield. The earliest attestation in the $O E D$, s.v. bristle, n., is brestel, Guy of Warwick (c. 1314).

eddre (278) 'blood vessel'. V: 'eddre, adren 278. f.'

$O E D$ s.v. eddre, n. gives only three attestations for the Middle English period.

efennwage (241) 'even-weight, counterpoise'. V: 'Efning 7 efenwage, evenwightigh 241. f. 19 .'

A rare gloss word in Old English (ebnwege, efenwage), glossing Lat. aequipensium. ${ }^{69}$ MED cites euen y waie [L equilibrata] from John Trevisa's translation of Bartholomaeus Anglicus's De proprietatibus rerum. ${ }^{70}$

forrganngell (238) 'predecessor'. V: 'Foregangell 7 bidell 238.'

$O E D$, s.v. foregengl, n. gives only one attestation; $M E D$, s.v. fore-gengel, gives three. A spelling with $<\mathrm{a}>$ is unrecorded.

fossterr (22) 'foster child'. V: 'Foster, i. voesterkint 22.'

OED, s.v. Foster n.1., 3.b., provides only one Middle English attestation of this meaning. In the glossary van Vliet drew a line to link up this lemma with Fosterfader.

naffle (239) 'navel'. V: 'Nafle 239.'

Van Vliet gives no translation.

\footnotetext{
${ }^{68}$ The transcripts of van Vliet's entries are preceded by V. and printed in italics. W/H = the glossary in Holt's 1878 edition. OED = Oxford English Dictionary Online Oxford University Press; MED = Middle English Dictionary Online University of Michigan; DOE = Dictionary of Old English: $A$ to $G$ on $C D-$ ROM (Cameron et al. 2008).

69 DOE s.v. efenwage.

70 MED s.v. ēven (adv.), sense 17, citation f.
} 
waterrdrope (221) 'water drop'. V: 'Drope, waterdrope 221. 1. 8.'

Although listing it under drope, it is likely that the word he found was waterdrope. In any case, neither form is attested in the Ormulum. OED, s.v. water drop, n., cites 'a1438' as the date of the first attestation of 'water-drop'.

3esype (?). V 'Zesype, respectus.'

Van Vliet gives no column number, and the entry may be corrupt. The translation 'a respected man' may point to a Middle English reflex of Old English gesip 'attendant'.

In spite of its rather basic layout and composition, this glossary gives evidence of van Vliet's increased interest in and knowledge of the Ormulum. The glossary contains no less than 57 entries that are listed as hapax legomena in White's/Holt's glossary, and many of the remaining lemmata occur fewer than four times in the entire manuscript, which suggests that van Vliet was deliberately searching for words that he had not encountered yet. Whatever his intentions were (three pages of a fairer Ormulum glossary survive in Lambeth 783, ff. 89r, 90r, 91r), van Vliet's untimely death in the spring of 1666 cut them short, and the Ormulum lost its most enthusiastic student for almost two centuries to come.

When the Ormulum came in the possession of Francis Junius, he was about seventy-five years old and had just published his magnum opus: the Gothic and Anglo-Saxon Gospels and the Gothic glossary (Junius and Marshall 1665). With more publication projects than he had time to complete, the Ormulum was clearly not a priority for Junius. The Summary Catalogue lists for MS Junius 37, ff. 6-13 'jottings from the Ormulum'; in fact, only ff. $6 \mathrm{v}$ and $9 \mathrm{v}$ to $13 \mathrm{r}$ contain a few Ormulum jottings; the rest is Old English from various sources (Madan et al. 1937: 973). ${ }^{71}$ The project for which the Ormulum would have been most suitable is the Etymologicum Anglicanum, Junius's etymological dictionary of English which was publised by Edward Lye in 1743 from MSS Junius 4 and 5. These manuscripts are remarkable in that their design enabled Junius to add entries over time to the original alphabetical sections, with entries on the verso sides of the leaves and the facing recto allowing space for pasted notes with additional material. While in the course of time Junius pasted in many citations from Chaucer's works and from Gavin Douglas's Middle Scots Eneados, the Ormulum is almost absent. There are citations in the entries on loppestere and fyndie, while Lye mentions in the printed edition that wenchel occurs several times in the Ormulum, but on the whole searching for Ormulum citations in the Etymologicum Anglicanum is like looking for a needle in a haystack (Junius 1743: 2x2v, 3s1r, 6i1v). Similarly rare are Ormulum references in Junius's handwritten Old English dictionary (MSS Junius 2 and 3). ${ }^{72}$ The lack of an Ormulum glossary from Junius's hand shows that he did not attach great importance to it, since for Junius the value attributed to such a text was typically expressed by its use in dictionaries and glossaries. With the arrival of the

\footnotetext{
71 Junius's citations are in long lines written consecutively, with metrical pointing.

72 See Oxford, Bodleian Library, MS Junius 2, f. 276v, s.v. hlafdig, where he adds 'Vide quoque Ormulum 59.i'; see Dekker (2000a: 336).
} 
Ormulum manuscript in the Bodleian Library in 1678 as part of Junius's bequest, the relative lack of interest shown by Junius carried on for another century and a half. Especially in the first two decades of its Oxonian existence an ominous silence surrounds the manuscript—something which Wanley's description and Hickes's citations did little to change. Nonetheless, the fact that Junius bought it and that it became part of his library probably ensured the preservation of this most unique medieval English manuscript. ${ }^{73}$

\section{Concluding Remarks}

Even though there is little printed evidence of the earliest Ormulum studies, the story of the Ormulum is not complete without an account of it. Van Vliet's examinations of the poem and manuscript are rare examples of a completely openminded approach to a text which has, since then, always suffered from preconceived notions that are less than positive. Hickes's classification of the Semi-Saxon dialect of the Ormulum and contemporaneous texts as soured wine slurred over the emergence of a reinvigorated new English language in the twelfth century. At the same time it confirmed the image of a corrupt Old English lasting up to the appearance of Chaucer's works. In the late seventeenth and early eighteenth centuries 'Middle English' was still an idea of the future, and even when that idea materialised in the late eighteenth and early nineteenth centuries the Ormulum played hardly any role (Matthews 2000). Although, van Vliet, too, became convinced that a 'classical' form of Old English differed from what he found in the Ormulum, he nonetheless displayed an endearing inquisitiveness born in part from the fact that he realised that the text was in verse. In many ways his Ormulum investigations were ahead of his time, while other aspects of his work, and especially his treatment of the manuscript, betrayed an attitude that was decidedly old-fashioned and which has complicated work on the Ormulum until today. No-one felt this more acutely than Robert Burchfield, whose herculean task of editing the manuscript ended up as an unfinished project. Undeniably, van Vliet's unwise tampering with the manuscript formed a major complication in his work on the edition-even though Burchfield's transcripts now constitute the most reliable Ormulum text in existence and are rightly used by the $O E D$ staff for their revision of entries. ${ }^{74}$ More than anything else, Burchfield's work demonstrates how important it is to know and understand the work of early philologists whose actions shaped the fates of medieval books.

\footnotetext{
73 It would not have been impossible for a manuscript like the Ormulum to end up as strips in book bindings. In the $1650 \mathrm{~s}$ binding strips from a manuscript of Ælfric's homilies were used by a bookbinder in The Hague (Fausbøll 1986; Bremmer and Dekker 2012: 39-41).

74 It is difficult to say what Burchfield's edition would have been like, since there is only an annotated transcript. Excellent work on the literary and theological aspects of the Ormulum has meanwhile been done, which has shed different light on its composition and purpose, and any new edition will need to take this into account. See, for example, McMullen (2014) and Guzmán (2004).
} 
Open Access This article is distributed under the terms of the Creative Commons Attribution 4.0 International License (http://creativecommons.org/licenses/by/4.0/), which permits unrestricted use, distribution, and reproduction in any medium, provided you give appropriate credit to the original author(s) and the source, provide a link to the Creative Commons license, and indicate if changes were made.

\section{References}

Alsbury, C. (2004). Aylesbury, Sir Thomas, baronet (1579/80-1658). In Oxford Dictionary of National Biography, online edn. Oxford: OUP.

Baber, H. H. (Ed.). (1810). The New Testament: Translated from the Latin in the year 1380, by John Wycliffe. London: R. Edwards.

Bennett, J. A. W. (1938). The history of Old English and Old Norse studies in England from the time of Francis Junius till the end of the eighteenth century. Unpublished Dissertation, Oxford.

Bernard, E. (Ed.). (1697). Catalogi librorum manuscriptorum Angliae et Hibernice in unum collecti (Vol. 2). Oxford: Sheldonian Press.

Bosworth, J. (1838). Dictionary of the Anglo-Saxon language. London: Longman et al.

Bremmer, R. H., Jr. (1998). Retrieving Junius's correspondence. In R. H. Bremmer Jr. (Ed.), Franciscus Junius F. F. and his circle (pp. 199-235). Amsterdam: Rodopi.

Bremmer, R. H., Jr., \& Dekker, K. (2012). Saint's lives and homilies, Anglo-Saxon manuscripts in microfiche facsimile 21. Tempe, AZ: ACMRS.

Bülbring, K. D. (1905). Die Schreibung des eo im Orrmulum. Bonner Beiträge zur Anglistik, 17, 51-82.

Burchfield, R. W. (1956). The language and orthography of the Ormulum MS. Transactions of the Philological Society, 55, 56-87.

Burchfield, R. (1961). Ormulum: Words copied by Jan van Vliet from parts now lost. In N. Davis \& C. L. Wrenn (Eds.), English and medieval studies presented to J. R. R. Tolkien on the occasion of his seventieth birthday (pp. 94-111). London: Allen and Unwin.

Burchfield, R. W. (1994). Line-end hyphens in the Ormulum manuscript (MS Junius 1). In M. Godden, D. Gray, \& T. Hoad (Eds.), From Anglo-Saxon to early modern English: Studies presented to E. G. Stanley (pp. 182-187). Oxford: Clarendon Press.

Cannon, C. (2007). Right writing: The Ormulum. In C. Cannon (Ed.), The grounds of English literature (pp. 83-110). Oxford: OUP.

Cameron, A., Crandell Amos, A., \& DiPaolo Healey, A. (2008). Dictionary of old English: A to G on CDROM. Toronto: Pontifical Institute.

Carlyle, E. I. (2009). White, Robert Meadows (1798-1865), rev. J. D. Haigh. In Oxford Dictionary of National Biography, online edn. Oxford: OUP.

Chamberlayne, J. (1915). Oratio dominica. Amsterdam: Willem and David Goeree.

Clerke, A. M. (1885). Aylesbury, Sir Thomas (1576-1657). In L. Stephen et al. (Eds.), Dictionary of National Biography (Vol. 20, p. 277). Oxford: OUP.

Conybeare, J. J., \& Conybeare, W. D. (1826). Anglo-Saxon poetry, edited together with additional notes, introductory notices, \& c. London: Richard Taylor.

Daemen-de Gelder, K., \& Vander Motten, J. P. (2010). A broken broker in Antwerp: William Aylesbury and the Duke of Buckingham's goods, 1648-1650. In P. Major (Ed.), Literatures of exile in the English Revolution and its aftermath, 1640-1690 (pp. 6-78). Farnham: Routledge.

Dekker, K. (1999). The origins of Old Germanic studies in the Low Countries, Brill's studies in intellectual history 92. Leiden: Brill.

Dekker, K. (2000a). "That most elaborate one of Francis Junius" An investigation of Francis Junius's manuscript Old English dictionary. In T. Graham (Ed.), The recovery of Old English: Anglo-Saxon studies in the sixteenth and seventeenth centuries (pp. 301-343). Kalamazoo: Medieval Institute Publications.

Dekker, K. (2000b). Francis Junius (1591-1677): Copyist or editor? Anglo-Saxon England, 29, $279-296$.

Durkin, P. (2014). Borrowed words: A history of loanwords in English. Oxford: OUP.

Faulkner, M. (2010-2013). Oxford, Bodleian Library, Junius 1. In O. Da Rold et al. (Eds.), The production and use of English manuscripts 1060 to 1220. http://www.le.ac.uk/english/ em1060to1220/mss/EM.Ox.Juni.1.htm. Accessed 12 June 2017.

Fausbøll, E. (1986). Fifty-six Alfric fragments: The newly-found Copenhagen fragments of Alfric's Catholic homilies; With facsimiles. Copenhagen: The University. 
Flacius Illyricus, M. (1571). Otfridi evangeliorum liber ueterum Germanorum grammatica; poesos, theologiae prcelarum monumentum. Euangelien Buch in altfrenckischen reimen duch Otfriden von Weissenburg, Münch zu S. Gallen vor sibenhundert jaren beschriben. Basel.

Guest, E. (1838). A history of English rhythms (Vol. 2). London: William Pickering.

Guzmán, M. (2004). Is Orrmulum's introduction an instance of an Aristotelian prologue? Neophilologus, 88, 477-492.

Harris, R. L. (1992). A chorus of grammars: The correspondence of George Hickes and his collaborators on the Thesaurus linguarum septentrionalium. Toronto: Pontifical Institute.

Harris, R. L. (1998). George Hickes (1642-1715). In H. Damico, D. Fennema, \& K. Lenz (Eds.), Medieval scholarship: Biographical studies on the formation of a discipline. Literature and philology (Vol. 2, pp. 19-32). New York: Garland.

Heyworth, P. L. (1989). Letters of Humfrey Wanley: Paleographer, Anglo-Saxonist, librarian, 1672-1726. Oxford: OUP.

Hickes, G. (1689). Institutiones grammaticae Anglo-Saxonicae et Moeso-Gothicae. Oxford: Sheldonian Press.

Hickes, G. (1703-1705). Linguarum vett. septentrionalium Thesaurus grammatico criticus et archaeologicus. Oxford: Sheldonian Press.

Holm, S. (1922). Corrections and additions in the Ormulum manuscript. Uppsala: Almqvist \& Wiksells.

Holt, R. (Ed.). (1878). The Ormulum, with the notes and glossary of Dr. R. M. White (Vol. 2). Oxford: OUP.

Innys, W., et al. (Eds.). (1747). Biographia britannica, or, the lives of the most eminent persons who have flourished in Great Britain and Ireland (Vol. I). London: W. Meadows et al.

Junius, F. (1655). Cadmonis monachi paraphrasis poetica Genesios a prcecipuarum sacra pagince historiarum, abhinc annos M.LXX. Anglo-Saxonicè conscripta, \& nunc primum edita. Amsterdam: Christoffel Koenraad. Repr. (2000) with an introduction by P. Lucas, Early Studies in Germanic Philology 3. Amsterdam/Atlanta: Rodopi.

Junius, F. (1743). Etymologicum Anglicanum. Ed. E. Lye. Oxford: Sheldonian Press.

Junius, F., \& Marshall, T. (1665). Quattuor D. N. Jesu Christi Euangeliorum versiones perantiquae duae, Gothica scil. et Anglo-Saxonica... Accessit \& Glossarium Gothicum: cui praemittitur alphabetum Gothicum, Runicum, \&c .... Dordrecht: Johan and Hendrik van Esch.

Ker, N. R. (1936). More of the Ormulum, Times Literary Supplement, 14 November.

Ker, N. R. (1940). Unpublished parts of the Ormulum printed from MS. Lambeth 783. Medium Avum, 9 , $1-22$.

Kölbing, E. (1877). Zur Textkritik des Ormulum. Englische Studien, 1, 1-16.

Kölbing, E. (1879). Review of The Ormulum, ed. R. Holt, 1878. Englische Studien, 2, 494-499.

Kössinger, N. (2009). Otfrids 'Evangelienbuch' in der frühen Neuzeit. Studien zu den Anfängen der deutschen Philologie. Tübingen: Niemeyer.

Lehnert, M. (1953). Sprachform und Sprachfunktion im Orrmulum (um 1200): Die Deklination. Berlin: Deutscher Verlag der Wissenschaften.

Macray, W. D. (1890). Annals of the Bodleian Library Oxford with a notice of the earlier library of the University (2nd ed.). Oxford: OUP.

Madan, F., Craster, H. H. E., \& Denholm-Young, N. (1937). A summary catalogue of western manuscripts in the Bodleian Library at Oxford (Vol. II, part II). Oxford: OUP.

Matthes, H. C. (1933). Die Einheitlichkeit des Orrmulum. Heidelberg: Winter.

Matthews, D. (2000). The invention of Middle English: An anthology of primary sources. University Park: Penn State University Press.

McCabe, S. (2011). Anglo-Saxon poetics in the Linguarum Veterum Septentrionalium Thesaurus Grammatico-Criticus et Archaeologicus of George Hickes: A translation. Diss. Univ. of New Mexico.

McMullen, A. J. (2014). forr pez̧re sawle need: The Ormulum, vernacular theology and a tradition of translation in Anglo-Saxon England. English Studies, 95, 256-277.

Menthel, E. (1885). Zur Geschichte des Otfridischen Verses im Englischen. Anglia, 8, 49-86.

Monicke, C. H. (1853, 1854). Notes and queries on the Ormulum. In A. Steinhaus (Ed.), Einladungsschrift zur Prüfung in der öffentlichen Handels-Lehranstalt zu Leipzig (pp. iii-iv, 1-36 [1853], 1-26 [1854]). Leipzig: Breitkopf und Härtel.

Niles, J. D. (2015). The idea of Anglo-Saxon England 1066-1901: Remembering, forgetting, deciphering, and renewing the past. Malden: Wiley. 
Palmer, R. (sine anno). Description of Lambeth Palace Library MS 783. Lambeth Palace Library. http:// archives.lambethpalacelibrary.org.uk/CalmView/Record.aspx?src=CalmView.Catalog\&id=MSS\% 2f783\&pos=2. Accessed 12 June 2017.

Parkes, M. B. (1983). On the presumed date and possible origin of the manuscript of the "Ormulum": Oxford Bodleian Library, MS Junius 1. In E. G. Stanley \& D. Gray (Eds.), Five hundred years of words and sounds. A festschrift for Eric Dobson (pp. 115-127). Cambridge: Brewer.

Petheram, J. (1840). An historical sketch of the progress and present state of Anglo-Saxon literature in England. London: Edward Lumley. Repr. (2000), with an introduction and bibliographical index by Karen Thomson. Edinburgh: The Stag Press.

Quarrie, P., et al. (2006). The library of the earls of Macclesfield removed from Shirburn Castle. Part seven: Bibles 1477-1739. London: Sotheby's.

Simpson, J. (2008). Burchfield, Robert William (1923-2004). Oxford Dictionary of National Biography: Oxford: OUP. Online edn. Accessed 1 Feb 2017.

Solopova, E. (1996). The metre of the Ormulum. In M. J. Toswell, \& E. M. Tyler (Eds.), Studies in English language and literature. 'Doubt wisely': Papers in honour of E. G. Stanley (pp. 423-439). London and New York: Routledge.

Stanley, E. G. (2004). Robert Burchfield: Workaholic Chief Editor of the Oxford English dictionaries, The Independent, 8 July.

Thorpe, B. (1834). Analecta Anglo-Saxonica: A selection of prose and verse from Anglo-Saxon authors of various ages with a glossary. London: John and Arthur Arch.

Todd, H. J. (1812). A catalogue of the archiepiscopal manuscripts in the library at Lambeth Palace. London: Law and Gilbert.

Turner, S. (1830). The history of England in the Middle Ages (Vol. V). London: Longman et al.

Turville-Petre, J. E. (1974). Studies on the Ormulum MS. The Journal of English and Germanic Philology, 46, $1-27$.

Tyrwhitt, T (1775-1778). The Canterbury Tales of Chaucer to which are added, an essay upon his language and versification; an introductory discourse; and notes, 5 vols. London: T. Payne.

Van Vliet, J. (1664). 't Vader ons in XX oude Duijtse en Noordse Taelen met d'uijtleggingen \&c. [Dordrecht: Johan and Hendrik van Esch].

Wanley, H. (1705). Librorum vett. septentrionalium, qui in Angliae bibliothecis extant... catalogus historico-criticus. Oxford: Sheldonian Press.

White, R. M. (Ed.). (1852). The Ormulum. Now first edited from the original manuscript in the Bodleian with notes and a glossary (Vol. 2). Oxford: OUP.

Wright, C. E. (1960). Humfrey Wanley: Saxonist and library keeper. Proceedings of the British Academy, 46, 99-129.

Wright, C. E., \& Wright, R. C. (1966). The diary of Humfrey Wanley 1715-1726 (Vol. 2). London: The Biographical Society.

Wright, T. (1846). Biographia Britannica literaria: Anglo-Norman period. London: John W. Parker.

Zonneveld, W. (2000). The 'Ormulum' and the 'Lutgart': Early Germanic iambs in context — Medieval English measures: Studies in metre and versification. Parergon, 18, $27-52$. 